\title{
Producer gas combustion in the internal combustion engine
}

\begin{abstract}
The investigation presented in the paper concerns producer gas combustion in both the spark ignited (SI) and the dual-fuel compression ignition (CI) engine with a diesel pilot of $15 \%$ with respect to its nominal dose, at compression ratio (CR) of 8, 12 (for the SI engine) and 17 (for the CI engine). The research tasks were mainly focused on combustion instabilities such as engine work cycles unrepeatability and combustion knock onset. The investigation included also combustion of such gases as methane, biogas and hydrogen, which were taken for making comparison between them and the producer gas. The conducted analysis shows that producer gas is resistant to generate knock even if it contains significant hydrogen content of $16 \%$. However, high work cycles unrepeatability is observed when producer gas is combusted in the SI engine. Obtained results led to conclusion that producer gas can be burnt more efficiently in the dual-fuel CI engine than the SI one. Neither misfiring nor knocking have occurred during its combustion in that engine.
\end{abstract}

Key words: IC engine, producer gas, knock

\section{Spalanie gazu generatorowego w tlokowym silniku spalinowym}

\begin{abstract}
W artykule opisano wyniki badań spalania gazu generatorowego w silniku z zapłonem iskrowym $i$ w silniku dwupaliwowym z pilotowa dawka oleju napędowego. Głównie skoncentrowano się na wyznaczeniu stabilności spalania tego gazu za pomoca współczynnika niepowtarzalności kolejnych cykli jego pracy oraz możliwości wystapienia spalania stukowego. $W$ celu porównania uzyskane wyniki przedstawiono łacznie z odpowiednimi wynikami dla spalania wodoru, metanu $i$ biogazu. Z przeprowadzonej analizy wynika, że gaz generatorowy w porównaniu do pozostałych gazów jest odporny na generowanie spalania stukowego pomimo znaczacej zawartości wodoru (do 16\%), jednakże silnik iskrowy zasilany tym gazem wykazuje względnie duża niestabilność kolejnych cykli spalania. Znacznie lepsza powtarzalność kolejnych cykli spalania zaobserwowano podczas spalania gazu generatorowego $w$ dwupaliwowym silniku wysokoprężnym z zaptonem inicjowanym pilotowa dawka oleju napędowego.
\end{abstract}

Słowa kluczowe: silnik spalinowy, gaz generatorowy, spalanie stukowe

\section{Introduction}

Investigation conducted in several research centers confirms usefulness of gaseous renewable fuels such as wood gas or digestion gas (also called biogas) to feed the internal combustion (IC) reciprocating engine [1, 2]. Producer gas obtained from organic waste gasification can also be applied as a fuel for the such the piston engine. Such the measure was undertaken more than once in past. Particularly, attempts to adapt the spark ignited (SI) engine to work on wood gas are known. In the paper results of indicating the engine fueled with modeled producer gas are presented. The gas was combusted in both the SI engine and the compression ignition (CI) engine with ignition initiated by a diesel pilot dose.

Producer gas combustion in the SI piston engine characterizes itself with high unrepeatability of consecutive engine work cycles, that is caused by relatively low combustibles content [3]. Furthermore, apart from combustibles as methane and carbon monoxide, hydrogen, which is prone to generate combustion knock, is presented in the producer gas. The knock especially appears in the engine with high compression ratio (CR). Therefore, the research of the producer gas fueled engine described in this paper was mainly focused on determination of work cycles unrepeatability and knock intensity defined here as maximal amplitude of combustion pressure fluctuations. Additionally, both these

\section{Wstęp}

Analizy prowadzone w wielu ośrodkach naukowych wykazują przydatność odnawialnych paliw gazowych takich jak gaz drzewny lub biogaz fermentacyjny do napędu silników tłokowych [1,2]. Gaz generatorowy pozyskiwany w wyniku zgazowania odpadów organicznych także może być wykorzystywany jako paliwo do silnika tłokowego. Takie przedsięwzięcie było w przeszłości już niejednokrotnie realizowane. Szczególnie znane są próby przystosowania silnika iskrowego do pracy na gazie drzewnym. W artykule przedstawiono wyniki badań indykowania silnika tokowego zasilanego modelowym gazem generatorowym. Badany gaz spalano zarówno w silniku z zapłonem iskrowym jak również w silniku wysokoprężnym z zapłonem inicjowanym przez pilotową dawkę oleju napędowego.

Spalanie gazu generatorowego w silniku tłokowym $\mathrm{z}$ zapłonem iskrowym charakteryzuje się dużą niepowtarzalnością kolejnych cykli pracy silnika co jest spowodowane relatywnie niewielką zawartością składników palnych $\mathrm{w}$ tym gazie [3]. Ponadto wśród gazów palnych poza metanem i tlenkiem węgla występuje wodór, który ma skłonności do generowania stuku. Stuk ten szczególnie wyraźnie się objawia w silniku o wysokim stopniu sprężania. Dlatego w badaniach koncentrowano się głównie na wyznaczeniu niejednostajności biegu silnika zasilanego gazem generato- 
quantities were also determined for combustion of methane, digestion gas (also called as biogas) and hydrogen performed on the same test bench with respect to make comparison between these fuels and the producer gas.

The engine work cycles unrepeatability is expressed by the coefficient of variance (COV) of indicated mean effective pressure (IMEP, $\mathrm{p}_{\mathrm{i}}$ ) following the equation:

$$
\operatorname{COVp} p_{i}=\frac{\text { Std } \cdot \text { Dev }(\text { IMEP) }}{\text { Mean (IMEP) }} \cdot 100 \%
$$

While, knock intensity of the $\mathrm{i}$ individual combustion event was defined as the maximal amplitude IP ${ }_{\text {maks, }}$ of highpass filtered combustion pressure fluctuations with cut-off frequency of $3.5 \mathrm{kHz}$. This pressure intensity of the series consisted of $n$ individual consecutive combustion events with the pressure intensity $\mathrm{IP}_{\text {maks,i }}$ was determined as the mean value $\mathrm{IP}_{\mathrm{sr}}$ computed as follows:

$$
\mathrm{IP}_{\mathrm{S} I}=\sum_{\mathrm{i}=1}^{\mathrm{n}} \mathrm{IP}_{\mathrm{maks}, \mathrm{i}}
$$

\section{Test bench description}

Research was conducted on the test bed described in details in [4]. The test bed consisted of an IC engine coupled with a power generator of $20 \mathrm{kVA}$, which worked as engine dynometer.

Engines taken to research were as follows:

- SI engine with $\mathrm{CR}=8$ or 12 and swept volume of $825 \mathrm{~cm}^{3}$ of the single cylinder. Originally the engine was 2 cylinder inline CI Deutz F2L511. One cylinder was modified to be able to work at spark ignition terms.

- modified CI Deutz F2L511 with CR of 17 and diesel fuel dose adjustable in wide range for research purpose.

Gases of the interest are presented in the Table 1.

\section{Results}

As far as low and highly diluted combustible content in the producer gas is concerned combustion duration of this gas is relatively long and requires significantly advanced spark timing in the SI engine. In the Fig. 1a exemplary plots of producer gas combustion pressure from 125 combustion events in the each series in the SI engine with 3 different spark timings at $\mathrm{CR}=12$ are depicted. As seen, there is high unrepeatability of combustion pressure traces in the each test series. After averaging, these series are presented as the $p-v$ plots in the Fig. 1b. Significant drop in the area of useful work can be observed with spark timing changing from -35 to $-20^{\circ}$ crank angle degrees (CA deg). rowym oraz intensywności pulsacji ciśnienia indykowanego, które przyjęto jako wiarygodny wskaźnik intensywności potencjalnego stuku. Dodatkowo, w celu porównania, obydwie wielkości wyznaczano także dla spalania metanu, biogazu i wodoru na tym samym stanowisku badawczym.

Niepowtarzalność kolejnych cykli pracy silnika wyrażano za pomocą współczynnika wariancji średniego ciśnienia indykowanego według wzoru (1).

Natomiast intensywność stuku wyrażano jako intensywność IP pulsacji ciśnienia indykowanego. Przebieg pulsacji ciśnienia uzyskiwano poprzez filtrowanie górno-przepustowe z częstotliwością graniczną $3,5 \mathrm{kHz}$ ciśnienia spalania. Intensywność tę dla serii pomiarowej złożonej z n cykli spalania obliczano jako wartość średnią $\mathrm{IP}_{\text {sr }}$ ze zbioru wartości maksymalnej amplitudy pulsacji IP ${ }_{\text {maks, } i}$ występujących w pojedynczych, kolejno po sobie następujących cyklach spalania według zależności (2).

\section{Opis stanowiska badawczego}

Badania przeprowadzono na stanowisku badawczym, szczegółowo opisanym w [4]. Stanowisko składało się z silnika spalinowego sprzęgniętego z prądnicą synchroniczną 20 kVA spełniającą funkcję hamulca.

Silniki użyte do badań były następujące:

- silnik z zapłonem iskrowym i stopniu sprężania $\varepsilon=8 \mathrm{i}$ 12 oraz pojemności skokowej $825 \mathrm{~cm}^{3}$. Silnik powstał w wyniku modyfikacji jednego z cylindrów silnika wysokoprężnego Deutz F2L511.

- zmodyfikowany silnik wysokoprężny Deutz F2L511 o stopniu sprężania $\varepsilon=17 \mathrm{z}$ możliwością ustawiania pilotowej dawki oleju napędowego.

Badaniom poddano gazy przedstawione w tabeli 1.

Table 1. Selected properties of gases used for investigation
Tabela 1. Wybrane własności gazów użytych do badań
\begin{tabular}{|l|c|c|c|c|c|}
\hline $\begin{array}{l}\text { Gas composition/sktad } \\
\text { gazu generatorowego }\end{array}$ & $\begin{array}{c}\text { Volumetric content/ } \\
\text { udziat objętościowy }\end{array}$ & $\begin{array}{c}\text { Energetic/ } \\
\text { udziat ener- } \\
\text { getyczny }\end{array}$ & $\begin{array}{c}\text { Digestion } \\
\text { gas/ } \\
\text { biogaz }\end{array}$ & $\begin{array}{c}\text { Methane/ } \\
\text { metan }\end{array}$ & $\begin{array}{c}\text { Hydro- } \\
\text { gen/ } \\
\text { wodór }\end{array}$ \\
\hline Hydrogen/ wodór & $16 \%$ & $50 \%$ & - & - & $100 \%$ \\
\hline $\begin{array}{l}\text { Carbon dioxide/ } \\
\text { dwutlenek węgla }\end{array}$ & $13 \%$ & $19 \%$ & $35 \%$ & - & - \\
\hline $\begin{array}{l}\text { Carbon monoxide/ } \\
\text { tlenek węgla }\end{array}$ & $16 \%$ & $0 \%$ & - & - & - \\
\hline Methane/metan & $3 \%$ & $31 \%$ & $65 \%$ & $100 \%$ & - \\
\hline Nitrogen/azot & $52 \%$ & $0 \%$ & - & - & - \\
\hline Molar weight/masa molowa $[\mathrm{kg} / \mathrm{kmol}]$ & 26.04 & 25.8 & 16 & 2 \\
\hline Lower heating value/wartość opałowa $\left[\mathrm{MJ}^{\prime} / \mathrm{Nm}^{3}\right]$ & 3.4 & 22.7 & 35.0 & 10.7 \\
\hline $\begin{array}{l}\text { Lower heating value of stoic. mixture/ } \\
\text { Wartość opatowa mieszanki stech. }\left[\mathrm{MJ} / \mathrm{Nm}^{3}\right]\end{array}$ & 3.4 & 3.16 & 3.33 & 3.16 \\
\hline A/F stech. [Nm $\left./ \mathrm{Nm}{ }^{3}\right]$ & & 0.98 & 6.2 & 9.52 & 2.38 \\
\hline
\end{tabular}

\section{Wyniki badań}

Ze względu na niewielką ilość substancji palnej i jej duże rozrzedzenie w gazie generatorowym jego przebieg spalania w silniku o zapłonie iskrowym jest względnie powolny i wymaga stosowania stosunkowo wczesnych kątów zapłonu. Na rysunku 1a pokazano fragmenty przykładowych przebiegów 

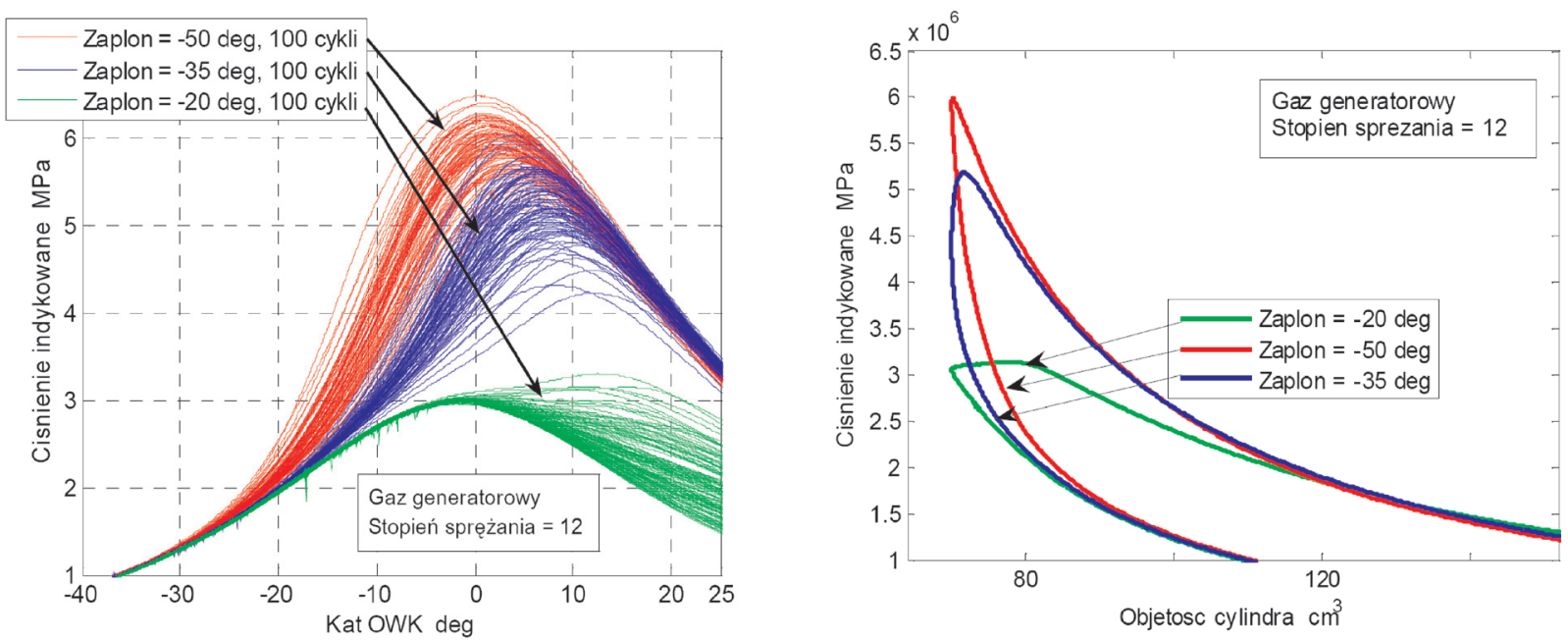

Fig. 1. Combustion pressure vs crank angle for producer gas combustion in the SI engine at CR of 12, stoich. mixture, with variable spark timing (ST) (a), pressure-volume (p-v) diagram for test series from the Fig. 1a (b)

Rys. 1. Fragment rozwiniętego wykresu indykatorowego przedstawiajacy spalanie gazu generatorowego $w$ silniku o $\varepsilon=12, \lambda=1$ (a), fragment uśrednionego zamkniętego wykresu indykatorowego dla serii pomiarowych z rys. la (b)

Increase in engine work cycles unrepeatability is also seen when someone compares plots in the Fig. 1a recorded from the engine with the CR of 12 and plots presented in the Fig. 2 taken from the engine with the $\mathrm{CR}$ of 8 . This increase was probably caused by lower temperature of combustible mixture at ignition, that also made the ignition lag much longer, even it had been relatively long.

Moreover, work cycles unrepeatability $\mathrm{COVp}_{\mathrm{i}}$ of producer gas combustion under optimal spark timing is the highest among the gases taken for investigation (Fig. 3). The minimum of $\mathrm{COVp}_{\mathrm{i}}$ is located for the spark timing in the range from $-45^{\circ}$ to $-30^{\circ} \mathrm{CA}$ deg.

In this range the highest IMEP $\left(\mathrm{p}_{\mathrm{i}}\right)$ is also observed (Fig. 4). Relatively low IMEP of the engine fueled producer gas in comparison with other gases is caused by low heating value of the producer gas-air mixture.

Due to hydrogen presence in the producer gas, weak resistance to combustion knock onset is expected. In the Fig. 5 mean intensity of pressure fluctuations $\mathrm{IP}_{\mathrm{sr}}$ computed as mean of fluctuation maximal amplitude from the each of 125 combustion events is depicted. As concluded from knock analysis, despite high compression ratio, producer gas (zawierających po 125 cykli) ciśnienia spalania gazu generatorowego dla różnych kątów zapłonu w silniku ZI o $\varepsilon=12$. Widoczna jest duża niepowtarzalność przebiegów ciśnienia dla pojedynczych cykli spalania. Po uśrednieniu ciśnienia serie te przedstawiono w postaci zamkniętego wykresu indykatorowego (rys. 1b). Można zauważyć znaczący spadek pola pracy użytecznej przy zmianie kąta zapłonu od -35 do $-20^{\circ}$.

W porównaniu do przebiegów z rys. 1a zarejestrowanych dla silnika o $\varepsilon=12$ zaobserwowano wzrost niepowtarzalności kolejnych cykli pracy (rys. 2) gdy stopień sprężania silnika zmniejszono do $\varepsilon=8$. Ten wzrost niepowtarzalności prawdopodobnie wynika zniższej temperatury w chwili zapłonu mieszanki palnej, co wydłuża i tak już względnie długą zwłokę zapłonu.

Ponadto, porównując ze sobą przebiegi ciśnienia spalania wodoru, metanu, biogazu i gazu generatorowego (rys. 3) przy optymalnie ustawionym kącie zapłonu można także zauważyć że spalanie gazu generatorowego wykazuje się najwyższą niepowtarzalnością $\mathrm{COVp}$ kolejnych cykli pracy silnika. Najniższa wartość $C O V p_{i}$ dla tego gazu występuje dla kąta zapłonu w przedziale od $-45^{\circ}$ do $-30^{\circ}$ OWK. W tym przedziale kąta zapłonu występuje również najwyższa wartość średniego ciśnienia indykowanego $\mathrm{p}_{\mathrm{i}}$.
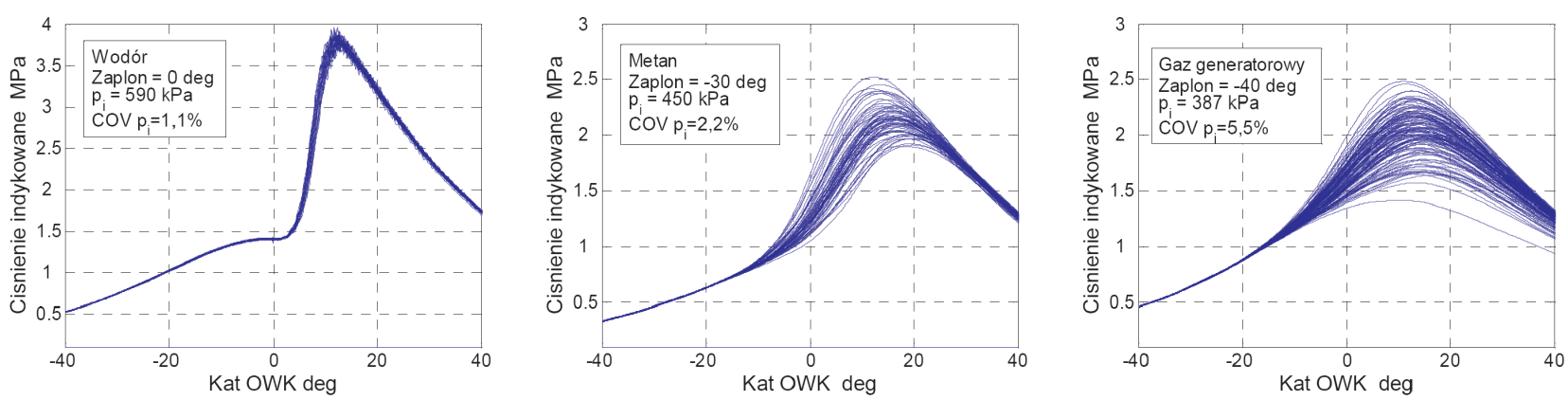

Fig. 2. Exemplary combustion pressure vs crank angle for hydrogen(a), methane (b) and producer gas (c) combustion in the SI engine at $\mathrm{CR}=8$ and stoich. mixture at optimal spark timing

Rys. 2. Przykladowe przebiegi serii pomiarowych złożonych z 125 cykli ciśnienia indykowanego dla wodoru (a), metanu (b) i gazu generatorowego (c) dla optymalnego kata zapłonu $w$ silniku ZI o $\varepsilon=8 i \lambda=1$ 


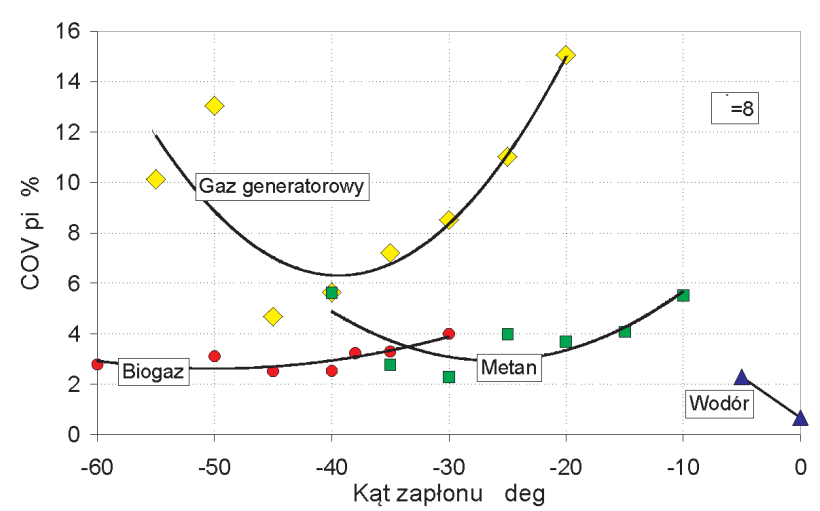

Fig. 3. COVp $\mathrm{p}_{\mathrm{i}}$ vs spark timing for combustion of selected gaseous fuels (methane, biogas, producer gas) in the SI engine at $\mathrm{CR}=8$ and stoichiometric mixture

Rys. 3. Zależność współczynnika wariancji (niepowtarzalności średniego ciśnienia indykowanego COVp.) dla wybranych gazów w funkcji kąta zapłonu przy częściowym otwarciu przepustnicy

does not generate knocking, which can be observed during methane or biogas combustion. Mean knock intensity coming from hydrogen combustion reached $5 \mathrm{MPa}$ and its maximum IP in individual combustion events was to $8 \mathrm{MPa}$, so to keep clarity of plots in the figure 5 the hydrogen knock intensity $\mathrm{IP}_{\text {sr }}$ was not inserted in the Fig. 5.

Furthermore, investigation on combustion of producer gas in the compression ignition dual fuel engine fueled with the diesel dose $(\mathrm{ON})$ reduced to $15 \%$ was conducted. Intensity of pressure fluctuations were also determined in this case. In the figure 6 a combustion pressure history vs crank angle for the CI dual fuel engine fueled with methane, biogas and producer gas is plotted. Someone can notice that unrepeatability of combustion events for these gases does not differ significantly between each and other.

Unrecognized combustion instability was observed during producer gas combustion in this engine, as shown in the Fig. 6b. This instability appeared as bi-stable combustion characterized with two stable values which were alternated. Mechanism of that combustion has not been explained so far. It can be supposed that cylinder exhaust residue can
W tym przedziale kąta zapłonu występuje też najwyższa wartość $\mathrm{p}_{\mathrm{i}}$ (rys. 4). Niewielkie średnie ciśnienie indykowane dla silnika zasilanego gazem generatorowym w porównaniu do silnika zasilanego metanem lub biogazem związane jest z relatywnie niedużą wartością opałową mieszanki tego gazu $\mathrm{z}$ powietrzem.

$\mathrm{Z}$ powodu występowania wodoru $\mathrm{w}$ gazie generatorowym, można spodziewać się skłonności do generowania stuku przez silnik zasilany takim gazem. Na rysunku 5 przedstawiono średnią wartość z maksymalnych amplitud pulsacji IP ${ }_{\text {sr }}$ występujących w pojedynczych cyklach spalania danej serii pomiarowej złożonej ze 125 cykli spalania. Z analizy pulsacji ciśnienia spalania wynika, że gaz generatorowy, pomimo stosowania względnie wysokiego stopnia sprężania, nie generuje stuku, który można zaobserwować podczas spalania metanu i biogazu. Aby zachować przejrzystość wykresu, nie zamieszczono intensywności pulsacji IP dla wodoru, ponieważ charakteryzowała się ona wartością dochodzącą do $5 \mathrm{MPa}$. A w przypadku pojedynczych cykli spalania niejednokrotnie wielkość IP przekraczała $8 \mathrm{MPa}$.

Badaniom poddano także spalanie gazu generatorowego w silniku wysokoprężnym zasilanym obniżoną do około $15 \%$ pilotową dawką oleju napędowego $(\mathrm{ON})$. Ponadto badano również intensywność pulsacji ciśnienia spalania w silniku przy tym sposobie zapłonu gazu generatorowego. $\mathrm{Na}$ rysunku 6 a przedstawiono przykładowe przebiegi ciśnienia spalania metanu, biogazu i gazu generatorowego w silniku dwupaliwowym z zapłonem inicjowanym pilotową dawką oleju napędowego. $Z$ przebiegów przedstawionych na rys. 6a można wywnioskować, że w silniku dwupaliwowym z pilotową dawką ON niepowtarzalność kolejnych cykli spalania gazu generatorowego niewiele się różni od spalania metanu lub biogazu.

Podczas spalania gazu generatorowego w tym silniku zauważono pewną niestabilność spalania, którą przedstawiono na rys. 6b. Niestabilność ta polegała na naprzemiennym generowaniu przebiegów spalania o dwóch różnych, ale stosunkowo stabilnych wartościach maksymalnego ciśnienia spalania. Dotychczas mechanizm tego zjawiska nie został wyjaśniony. Przypuszcza się, że przyczyną takiego bistabilnego przebiegu
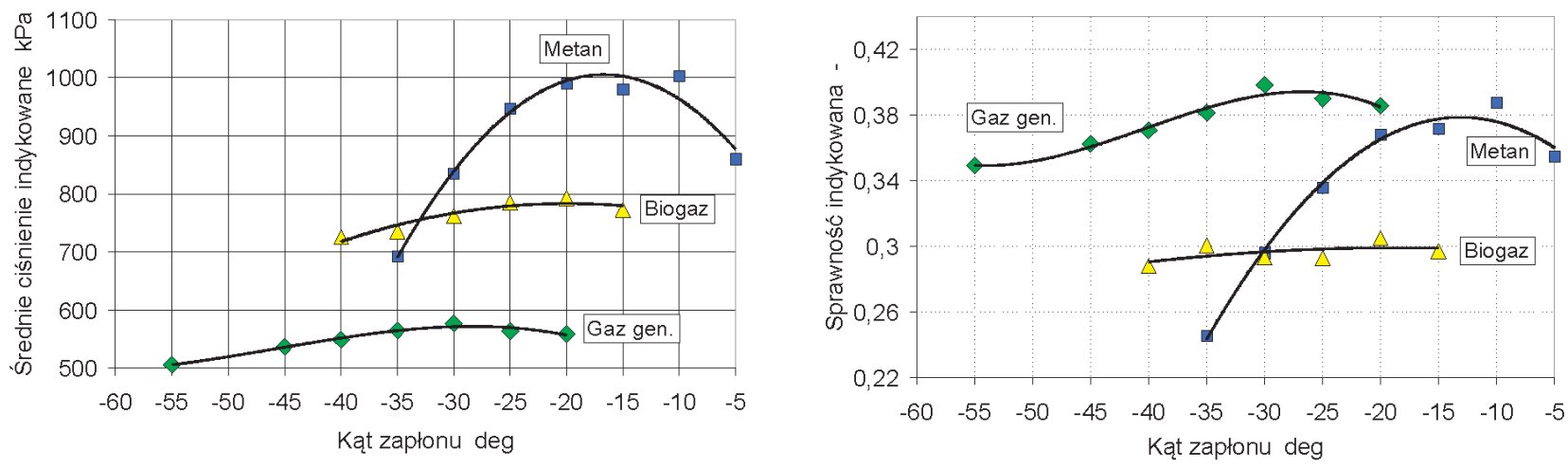

Fig. 4. Indicated mean effective pressure (IMEP) vs spark timing (a), gross indicated efficiency vs spark timing for the SI engine at CR $=12$ and stoichiometric mixtures of methane, biogas and producer gas

Rys. 4. Średnie ciśnienie indykowane w funkcji kąta zapłonu dla wybranych paliw gazowych w silniku o stopniu sprężania $\varepsilon=12$ (a), sprawność indykowana brutto (b) 


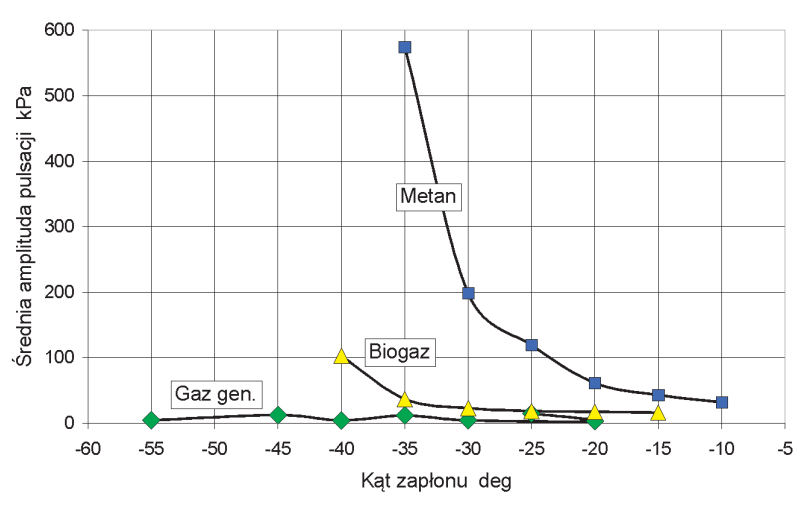

Fig. 5. Averaged maximal amplitude of high frequency filtered combustion pressure vs spark timing for methane, biogas and producer gas combustion in the SI engine at $\mathrm{CR}=12$

Rys. 5. Średnia z maksymalnych amplitud pulsacji IP ${ }_{\text {sr }}$ (dla serii złożonej ze 100 cykli) w funkcji kąta zapłonu dla wybranych paliw gazowych w silniku o stopniu sprężania $\varepsilon=12$

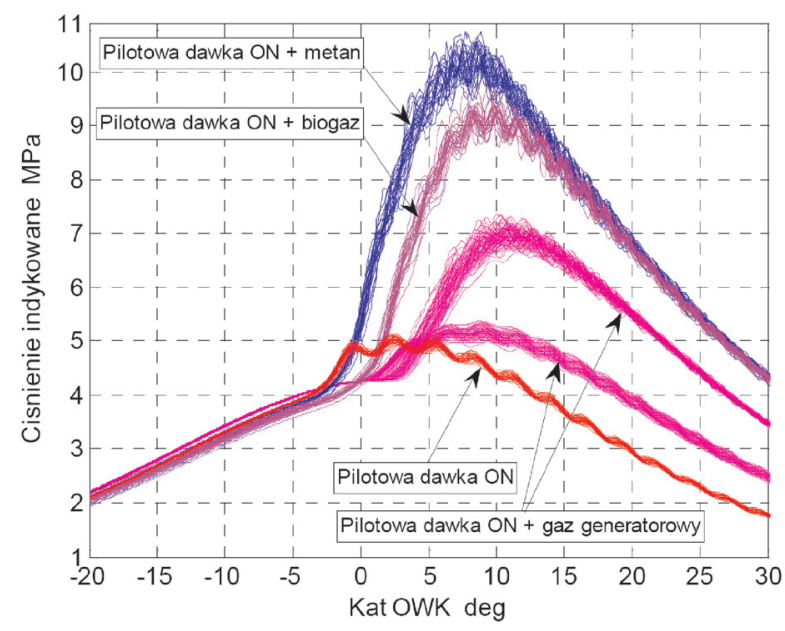

spalania może być inna po każdym cyklu pozostałość reszty spalin, która znacząco wpływa na przebieg spalania gazu o niewielkiej kaloryczności, i której ilość m.in. zależy od ciśnienia wydechu. Zatem pozostałość reszty spalin i przebieg ciśnienia spalania mogą zmieniać się bistabilnie, nawzajem podtrzymując zaobserwowane zjawisko. Zauważono, że ze wzrostem dawki pilotowej ON zjawisko to zanika.

Intensywność pulsacji ciśnienia $\mathrm{IP}_{\mathrm{sr}} \mathrm{W}$ silniku dwupaliwowym była nieco wyższa, aniżeli $\mathrm{w}$ silniku ZI przy spalaniu tych samych gazów. Jednakże spalanie stukowe nie występowało, a pulsacje ciśnienia były wyższe, ponieważ sprzyjał temu inny kształt komory spalania, a także przebieg spalania mieszaniny gazu z olejem napędowym był bardziej gwałtowny, co wykazano za pomocą maksymalnej wartości przyrostu ciśnienia spalania dp/d $\theta$ (tabela 2 ). Na rysunku 7 zestawiono wyniki średniej intensywności pulsacji ciśnienia IP ${ }_{\text {sr }}$ dla różnych gazów spalanych w silniku ZI i silniku dwupaliwowym ZS. Intensywne spalanie stukowe można

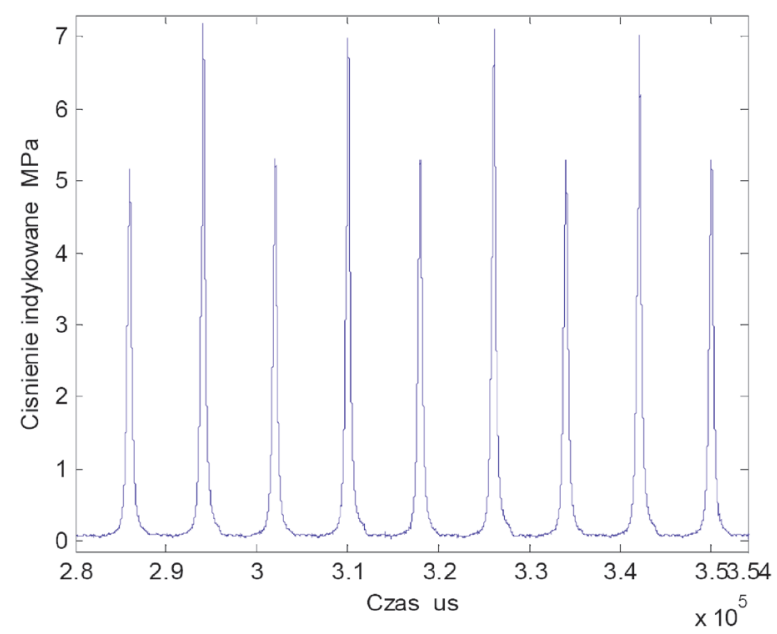

Fig. 6. In-cylinder combustio npressure vs crank angle for combustion of selected gaseous fuels with the $15 \%$ diesel pilot in the compression ignition (CI) engine at $\mathrm{CR}=17$ (a), bi-stable combustion pressure in the producer gas + diesel fuel combustion in the $\mathrm{CI}$ engine

Rys. 6. Serie przebiegu ciśnienia indykowanego $w$ dwupaliwowym silniku ZS o $\varepsilon=17$ zasilanym gazem generatorowym, metanem i biogazem z pilotowa dawka ON (a), dwutaktowy przebieg spalania gazu generatorowego (b)

contribute to generate such the bi-stable combustion. The incylinder exhaust residue amounts can vary itself with various exhaust pressure. Combustion duration of the low calorific producer gas can differ significantly when the gas is extra diluted with various exhaust residue amounts. Thus, both the exhaust residue and exhaust pressure are the quantities which can vary and assume two stable values supporting this bi-stable combustion. With increasing the diesel pilot dose the bi-stable combustion phenomena slightly disappeared.

Combustion pressure fluctuations intensity $\mathrm{IP}_{\mathrm{sr}}$ in the dual fuel CI engine was slightly higher than in the SI engine fueled with the same gases. However combustion knock does not occur but pressure fluctuations were higher because of different combustion chamber shape and other, more rapid combustion process of diesel dose and gas when compared with the SI engine. The combustion rate of the mentioned fuels in these engines is expressed by maximum of the combustion pressure rate maks. $\mathrm{dp} / \mathrm{d} \theta$, which is shown in the Table 2. Summary of było zaobserwować podczas spalania wodoru zarówno w silniku ZI jak i ZS. W przypadku pozostałych gazów niewielki stuk obserwowano przy spalaniu metanu i biogazu w dwupaliwowym silniku ZS.

\section{Wnioski}

1. Spalaniu gazu generatorowego w silniku wolnossącym z zapłonem iskrowym towarzyszy duża niepowtarzalność kolejnych cykli pracy takiego silnika. Natomiast intensywność pulsacji ciśnienia spalania, na podstawie której można by wnioskować o występowaniu spalania stukowego w silniku ZI jest marginalna, nawet wówczas gdy stopień sprężania tego silnika wynosi $\varepsilon=12$ a zawartość wodoru w gazie jest na poziomie około $16 \%$.

2. Na podstawie przeprowadzonych badań można stwierdzić, że ze względu na występowanie bardzo intensywnego spalania stukowego, niecelowe jest spalanie czystego wodoru w silniku dwupaliwowym z pilotową dawką oleju 
Table 2. Maximum of $\mathrm{dp} / \mathrm{d} \theta$ for selected gaseous fuels burnt in the SI and the $\mathrm{CI}$ engines

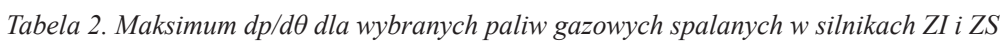

\begin{tabular}{|c|c|c|c|c|c|c|c|c|c|c|}
\hline Engine/silnik & & \multicolumn{4}{|c|}{ Engine $\mathrm{SI} /$ silnik $Z I, \varepsilon=12$} & \multicolumn{5}{|c|}{ Engine $\mathrm{CI} /$ silnik $Z S, \varepsilon=17$} \\
\hline Fuel/paliwo & - & $\mathrm{H}_{2}$ & $\mathrm{CH}_{4}$ & $\begin{array}{l}\text { Digestion } \\
\text { gas/biogaz }\end{array}$ & $\begin{array}{l}\text { Producer gas/ } \\
\text { gaz gen. }\end{array}$ & $\begin{array}{c}\mathrm{H}_{2}+15 \% \\
\text { Diesel/ } \\
\mathrm{H}_{2}+15 \% \mathrm{ON}\end{array}$ & $\begin{array}{c}\mathrm{CH} 4+15 \% \\
\text { Diesel/ } / \mathrm{CH}_{4} \\
+15 \% \mathrm{ON}\end{array}$ & $\begin{array}{l}\text { Digestion } \\
\text { gas }+15 \% \\
\text { Diesel/biogaz } \\
+15 \% O N\end{array}$ & $\begin{array}{c}\text { Producer } \\
\text { gas }+15 \% \\
\text { Diesel/gaz gen } \\
+15 \% O N\end{array}$ & $\begin{array}{c}\text { Diesel/ } \\
\text { ON }\end{array}$ \\
\hline $\max . \mathrm{dp} / \mathrm{d} \theta$ & $\mathrm{MPa} / \mathrm{deg}$ & 0.49 & 0.37 & 0.36 & 0.24 & 0.95 & 1.2 & 1.1 & 0.45 & 0.88 \\
\hline
\end{tabular}

the $\mathrm{IP}_{\mathrm{sr}}$ values obtained from the research is presented in the Fig. 7. Highly intensive combustion knock was observed in the both SI and CI engines with hydrogen as the applied fuel. Light knock was generated in case of fueling these engines with methane or biogas.

\section{Conclusions}

1. High work cycles unrepeatability is observed for producer gas combustion in the freely aspirated SI engine. However combustion pressure fluctuations intensity as symptoms of combustion knock can be neglected in the SI engine even if compression ratio of the engine is assumed 12 and the producer gas contains hydrogen of $16 \%$.

2. On the basis of conducted research someone concludes that high combustion knock occurring during hydrogen combustion in the dual fuel engine makes usefulness of this gas as the engine fuel unjustified. On the other hand, combustion of gases rich in hydrogen content should not provide any difficulties as far as knock is concerned. Moreover, carbon dioxide as the gas content at amounts comparable to hydrogen significantly strengthens resistance of such a gas to knock onset. Producer gas can be considered as such the gas, which generates pressure fluctuations not higher than fluctuations from combustion of diesel fuel in the dual fuel CI engine.

The work was done as a part of the research developed project R10 01902 sponsored by the Ministry of Science and Higher Education of Poland.

Paper reviewed/Artykut recenzowany

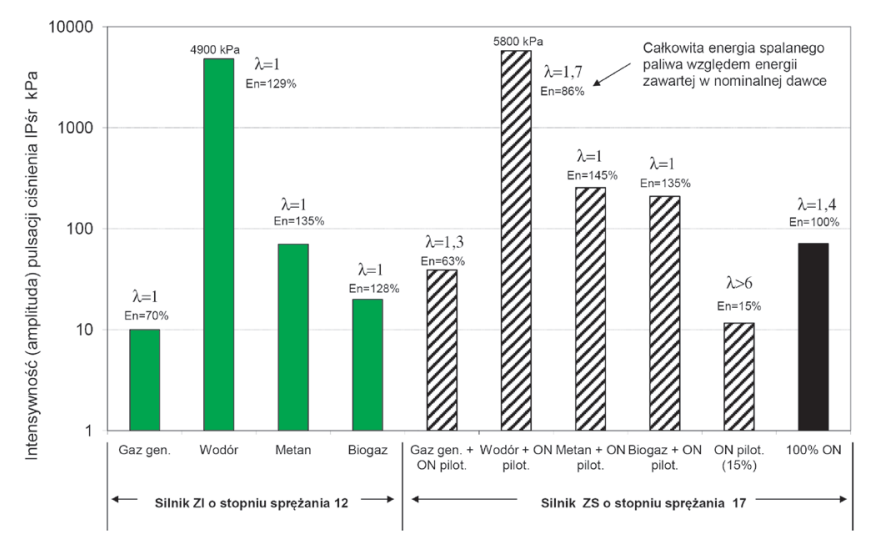

Fig. 7. Comparison of the pressure pulsations intensity IP from selected gaseous fuels (producer gas, hydrogen, methane, biogas) combustion in the SI engine and the CI dual fuel engine

Rys. 7. Porównanie amplitudy pulsacji ciśnienia spalania IP ${ }_{s r}$ podczas spalania wybranych paliw gazowych $w$ silniku ZI o $\varepsilon=12 i \mathrm{w}$ silniku ZS $o \varepsilon=17$ z pilotowa dawka $O N$

napędowego. Jednakże nie powinno nastręczać trudności spalanie w silniku dwupaliwowym gazów, w których wodór jest jednym z gazów palnych, a ponadto występuje w nich dwutlenek węgla w ilości porównywalnej objętościowo do ilości wodoru. Takim gazem jest gaz generatorowy, który podczas spalania generuje pulsacje ciśnienia o amplitudzie średniej, nie większej, aniżeli w przypadku spalania wyłącznie oleju napędowego w tym silniku.

Prace wykonano w ramach grantu rozwojowego $R 10019$ 02 finansowanego przez Ministerstwo Nauki i Szkolnictwa Wyższego.

[2] Török A.: Theoretical estimation of the environmental impact of biofuel mixtures, Transport 24(1): 26-29, 2009.

[3] Szwaja S.: Hydrogen rich gases combustion in the IC engine, Journal of Kones, Vol.16, No.4, 447-455, 2009.

[4] Borecki R., Szwaja S., Pyrc M.: Dual-fuel hydrogen-diesel compression ignition engine, Journal of Kones, Vol.15, No.2, 49-56, 2008

Prof. Karol Cupiał, DSc., DEng. - Professor in the Faculty of Mechanical Engineering and Computer Science at Częstochowa University of Technology.

Prof. dr hab. inż. Karol Cupial-Profesor na Wydziale Inżynierii Mechanicznej i Informatyki Politechniki Częstochowskiej.

e-mail: cupial@imc.pcz.czest.pl

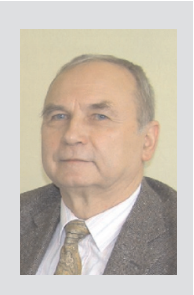

Mr. Stanisław Szwaja, DEng. - doctor in the Faculty of Mechanical Engineering and Computer Science at Częstochowa University of Technology.

Dr inż. Stanisław Szwaja - adiunkt na Wydziale Inżynierii Mechanicznej i Informatyki Politechniki Częstochowskiej.

e-mail: szwaja@imc.pcz.czest.pl 